\title{
Pengaruh Waktu dan Suhu Proses Elektrolessplating Nikel terhadap Karakteristik Fisik dan Mekanik Plastik ABS
}

(The Effect of Electroplasting Time and Temperature on Physiscal and Mechanical Properties of ABS Plastic)

\author{
MUHAMMAD BUDI NUR RAHMAN, CAHYO BUDIYANTORO, SUNARDI
}

\begin{abstract}
ABSTRAK
Plastik ABS digunakan dalam industri otomotif, rumah tangga dan elektronik karena kekuatannya tinggi, keras, liat, tahan korosi, tahan panas, mudah dibentuk dan bisa dilapisi. Electrolessplating nikel adalah teknik metalizing bahan non logam agar bersifat logam. Penelitian proses electrolessplating nikel pada plastik $\mathrm{ABS}$ dilakukan dengan variasi suhu elektrolit yaitu $40^{\circ} \mathrm{C}, 50^{\circ} \mathrm{C}, 60^{\circ} \mathrm{C}$, dan $70^{\circ} \mathrm{C}$ dan waktu proses pelapisan selama 4, 6, 8, 10 dan 12 menit. Karakterisasi yang dilakukan adalah mengetahui struktur mikro dan ketebalan lapisan menggunakan mikroskop optik, dan karakteristik mekanik meliputi, pengujian kekasaran, kekerasan menggunakan Shore D Hardness dan pengujian keausan. Peningkatan suhu elektrolessplating meningkatkan kekasaran permukaan dari $0,170 \mu \mathrm{m}$ pada suhu $40^{\circ} \mathrm{C}$ menjadi $0,422 \mu \mathrm{m}$ pada suhu $70^{\circ} \mathrm{C}$ sedangkan semakin lama proses elektrolessplating dapat menghaluskan permukaan dari $0,70 \mu \mathrm{m}$ untuk waktu 4 menit menjadi $0,33 \mu \mathrm{m}$ untuk waktu 12 menit. Peningkatan suhu dan waktu proses elektrolessplating menurunkan nilai keausan spesifik dari $1,9 \times 10^{-3} \mathrm{~mm}^{2} / \mathrm{kg}$ pada suhu $40^{\circ} \mathrm{C}$ menjadi $0,4 \times 10^{-3} \mathrm{~mm}^{2} / \mathrm{kg}$ untuk suhu $70^{\circ} \mathrm{C}$ dan $2,62 \times 10^{-3} \mathrm{~mm}^{2} / \mathrm{kg}$ pada waktu 4 menit menjadi $0,66 \times 10^{-3} \mathrm{~mm}^{2} / \mathrm{kg}$ untuk waktu 12 menit. Suhu dan waktu proses elektrolessplating tidak banyak meningkatkan nilai kekerasan rata-rata sebesar 84,5 SDH. Proses electrolessplating nikel pada suhu $50^{\circ} \mathrm{C}$ menghasilkan ketebalan lapisan optimum sebesar 5,56 $\mu \mathrm{m}$ karena ion yang terbentuk semakin banyak namun pada suhu $60^{\circ} \mathrm{C}$ dan $70^{\circ} \mathrm{C}$ ketebalannya berkurang sebesar $4,57 \mu \mathrm{m}$ dan 3,72 $\mu \mathrm{m}$. Penambahan waktu proses electrolessplating meningkatkan ketebalan lapisan, dari 1,29 $\mu \mathrm{m}$ dalam waktu 4 menit menjadi $3,98 \mu \mathrm{m}$ dalam waktu 12 menit karena ion yang mengendap pada permukaan semakin banyak.
\end{abstract}

Kata kunci: Elektrolessplating nikel, plastik ABS, suhu pelapisan, waktu pelapisan.

\section{ABSTRACT}

ABS plastic is used in the automotive, household and electronic industries because of its high strength, hardness, clay, corrosion resistance, heat resistance, easy to form and can be coated. Nickel electrolessplating is a technique of metalizing nonmetal materials to be metal. Research on the nickel electrolessplating process in $A B S$ plastic was carried out with variations in the temperature of the electrolyte that is $40^{\circ} \mathrm{C}, 50^{\circ} \mathrm{C}, 60^{\circ} \mathrm{C}$, and $70^{\circ} \mathrm{C}$ and coating time for $4,6,8,10$, and 12 minutes. Hardness and wear testing. An increase in temperature electro-less plating increase the surface roughness of $0.170 \mu \mathrm{m}$ at a temperature of $40^{\circ} \mathrm{C}$ to $0,422 \mu \mathrm{m}$ at a temperature of $70^{\circ} \mathrm{C}$, while the longer process of electroless plating smooth the surface of from $0.70 \mu \mathrm{m}$ to 4 minutes to $0.33 \mu \mathrm{m}$ for 12 minutes. An increase in temperature and the process time electro-less plating lower the value of wear specific than $1,9 \times 10^{-3} \mathrm{~mm}^{2} / \mathrm{kg}$ at a temperature of $40^{\circ} \mathrm{C}$ to $0,4 \times 10^{-3} \mathrm{~mm}^{2} / \mathrm{kg}$ for a temperature of $70^{\circ} \mathrm{C}$ and $2,62 \times 10^{-3} \mathrm{~mm}^{2} / \mathrm{kg}$ at the time of 4 minutes to $0,66 \times 10^{-3}$ $\mathrm{mm}^{2} / \mathrm{kg}$ for 12 minutes. The temperature and time of process electroless-plating not much increase the value of an average hardness of 84,5 SDH. The nickel electrolessplating process at a temperature of $500 \mathrm{C}$ produces an optimum layer thickness of $5.56 \mu \mathrm{m}$ because more and more ions are formed but at a temperature of $60 \mathrm{oC}$ and $70 \mathrm{oC}$ the thickness decreases by $4.57 \mu \mathrm{m}$ and $3.72 \mu \mathrm{m}$. The addition of electroless-plating process time increases the thickness of the layer, from $1.29 \mu \mathrm{m}$ in 4 minutes to $3.98 \mu \mathrm{m}$ in 12 minutes because more ions settle on the surface.

Keywords: ABS plastic, Coating temperature, Coating time, Nickel electrolessplating 


\section{PENDAHULUAN}

Plastik Acrylonitrile butadiene styrene (ABS) adalah polimer thermoplastic yang digunakan di industri otomotif, elektronik, dan peralatan rumah tangga karena memiliki stabilitas dimensi yang baik, kemampuan kejut dan kekenyalan yang tinggi sehingga cocok diaplikasikan untuk komponen yang bergerak (Zohari \& Kusmono, 2013). Plastik ABS dibentuk dari 3 monomer yaitu Acrylonitrile butadiene styrene di mana Acrylonitrile adalah sintesis monomer yang memiliki kekuatan tinggi, stabil terhdap panas dan tahan terhadap kimia, butadiena memiliki ketahanan impak dan ketangguhan yang tinggi, sedangkan stirena bersifat kaku dan mudah dibentuk. Berdasarkan sifat dasar tersebut yang paling penting adalah ketahanan terhadap impak dan toughness yang tinggi (Mujiarto, 2005). Polibutadiena merupakan bahan sejenis karet yang terdistribusi acak di dalamnya secara selektif dari matrik dan membuat lubang mikroskopis. Karakteristik khusus ini membuat plastik ABS mampu dilapisi dengan elektrolessplating. Elektrolessplating merupakan metode pelapisan logam tanpa menggunakan listrik. Pembentukan lapisan logam pada proses elektrolessplating terjadi karena reaksi oksidasi dan reduksi pada permukaan material dari garam logam tersebut (Harper, 2006). Plastik ABS memiliki tingkat keberhasilan electroplating tinggi disbanding plastic lain, karena plastik ABS secara kimiawi mudah dietsa sehingga adanya pori-pori akan meningkatkan daya adhesive yang tinggi antara permukaan plastic dengan logam pelapis
Senyawa nikel paling tepat untuk electrolessplating sebagai lapisan dasar yang banyak digunakan di industri. Senyawa nikel digunakan lapisan yang dihasilkan merata mengikuti kontur permukaan material, tidak terjadi penebalan dan kekasaran yang rendah pada sudutnya. Lapisan nikel akan meningkatkan daya hantar listrik, kekerasan, ketahanan aus, ketahanan abrasi, ketahanan korosi, dan memperbaiki penampilan permukaan menjadi mengkilap (Andinata \& Munasir, 2013). Suhu larutan sangat berpengaruh terhadap kecepatan pelapisan nikel pada proses elektrolessplating. Peningkatan suhu dan waktu perendaman menyebabkan ionion Ni-P menghasilkan lapisan yang seragam. Perlakuan panas juga meningkatkan komposisi nikel dan posfor (Nurhakim, dkk., 2017). Variasi suhu larutan elektrolessplating menjadi hal harus diperhatikan terutama untuk menghindari terjadinya dekomposisi lapisan nikel akibat kurang stabilnya larutan nikel pada suhu yang lebih tinggi. Proses elektrolessplating dikerjakan tanpa menggunakan arus listrik sehingga proses pelapisan terjadi menjadi sangat lambat karena pergerakan ion-ion logam dalam larutan juga lambat. Untuk mempercepat proses pelapisan maka suhu proses harus dinaikkan sampai suhu tertentu menggunakan alat pemanas. Terjadinya endapan logam yang melapisi plastik berlangsung secara otokatalitik di mana endapan terjadi terus-menerus karena reduksi kimia dari ion logam yang berasal dari dalam larutan dengan bantuan zat reduktor yang terkandung dalam larutan (Wang, et.al., 2018). Skema alat yang digunakan seperti pada Gambar 1.

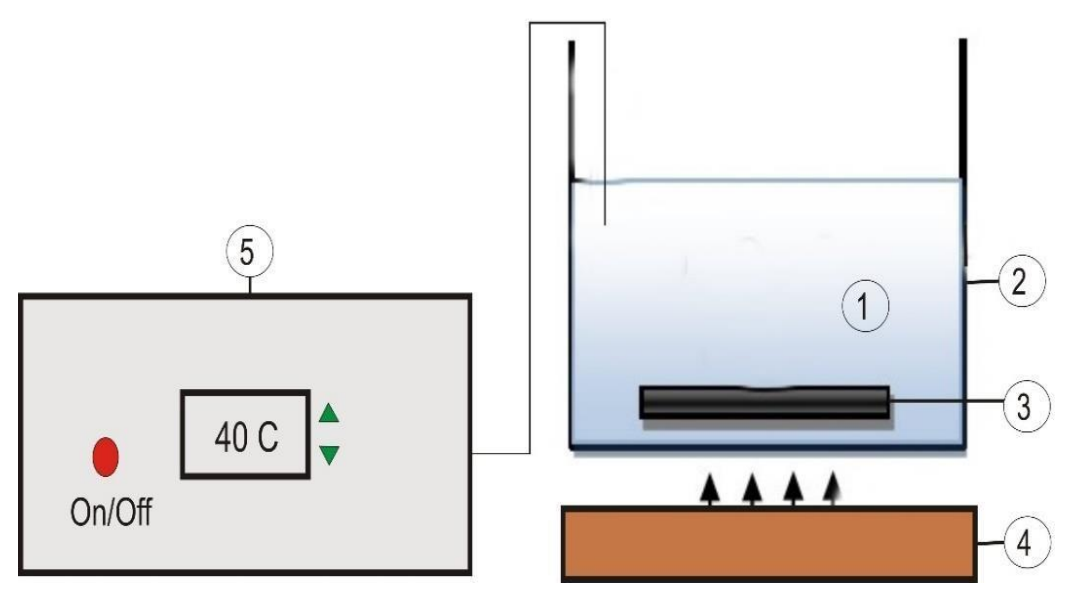

Gambar 1. Skema proses electrolessplating dengan 1)larutan elektrolessplating, 2)bak plating, 3)bahan yang dilapisi (Plastik ABS), 4)pemanas (heater), 5)thermocontrol 
Penelitian untuk mengetahui pengaruh waktu pencelupan electroplating nikel selama 20 menit, 30 menit, dan 40 menit dengan rapat arus 5 ampere terhadap ketebalan lapisan pada pembuatan dies menghasilkan ketebalan terbesar pada waktu pencelupan 40 menit sebesar $30 \mu \mathrm{m}$ dan ketebalan paling kecil pada waktu pencelupan 20 menit sebesar 22,5 $\mu \mathrm{m}$. Semakin lama waktu pencelupan proses electroplating maka lapisan yang terbentuk semakin tebal(Santhiarsa, 2016)

Pelapisan plastik ABS dengan krom diawali dengan proses aktivasi dengan pelapisan nikel dan pelapisan palladium dengan metode elektrolessplating. Pelapisan logam pada plastic ABS tidak jauh berbeda dengan electroplating pada logam, dengan menambah tahapan proses awal meliputi tahap etching, tahap netralisasi, tahap aktivasi, dan tahap elektrolessplating. Proses elektrolessplating nikel dengan memvariasikan waktu pencelupan specimen kedalam larutan. Hasil elektrolessplating dilihat dari lapisan logam nikel menempel dengan baik dan merata pada permukaan plastik. Proses electroplating krom dipengaruhi oleh variabel arus listrik, waktu electroplating dan komposisi larutan. Daya rekatan lapisan logam dengan plastic sebagai bahan dasar sangat tergantung proses elektrolessplating. Tingkat keberhasilan proses electroplating pada pelapisan plastic ABS dapat dilihat dari tingkat kecerahan lapisan, kekerasan setlah pelapisan, dan ketebalan lapisan. Peningkatan nilai kekerasan permukaan, ketahanan gesekan, ketebalan lapisan, dan perbaikan kekasaran permukaan disebabkan oleh pelepasan electron pada plastic
ABS pada saat proses etching dan aktivasi palladium (Zohari dan Kusmono, 2013).

Penelitian tentang pelapisan untuk proses metalisasi plastic ABS dengan metode elektrolessplating nikel dilakukan dengan variabel suhu larutan yaitu $30^{\circ} \mathrm{C}, 40^{\circ} \mathrm{C}$, dan $50^{\circ} \mathrm{C}$ dan waktu pelapisan elektrolessplating selama 5 menit, 10 menit, dan 15 menit. Nilai kekerasan hasil electrolessplating paling tinggi terdapat pada proses dengan suhu $50^{\circ} \mathrm{C}$ selama 15 menit sebesar 17,57 VHN (Santhiarsa, 2010).

Proses elektrolessplating melalui beberapa tahap yang berkesinambungan. Hasil setiap tahapan akan mempengaruhi hasil tahapan berikutnya. Kegagalan pada proses elektrolesplating maka specimen tidak bisa dilanjutkan unstuck proses electroplating berikutnya. Penelitian ini mengembangkan penelitian sebelumnya yaitu mengetahui pengaruh waktu dan suhu proses elektrolessplating terhadap karakteristik sifat fisik dan mekanik yang dilakukan pada plastic ABS.

\section{MetOde PENELITIAN}

Penelitian menggunakan specimen plastic ABS dengan ukuran panjang $80 \mathrm{~mm}$, lebar $7 \mathrm{~mm}$ dengan tebal $3 \mathrm{~mm}$, seperti yang terlihat pada Gambar 2. Proses penelitian yang dilakukan seperti yang terlihat pada Gambar 3.
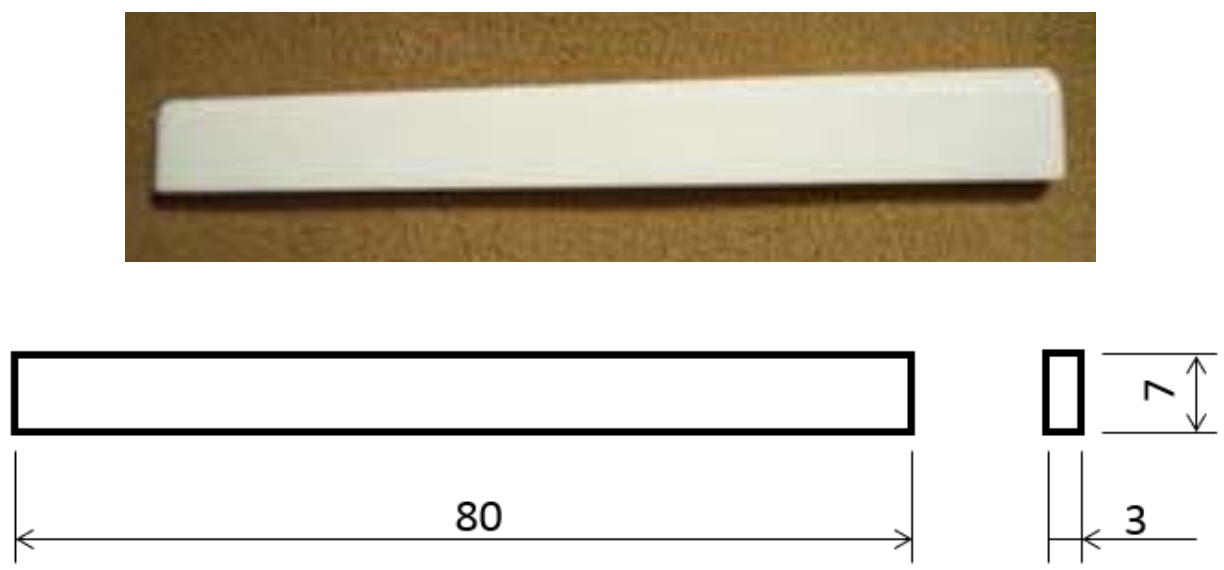

Gambar 2. Spesimen Plastik ABS 


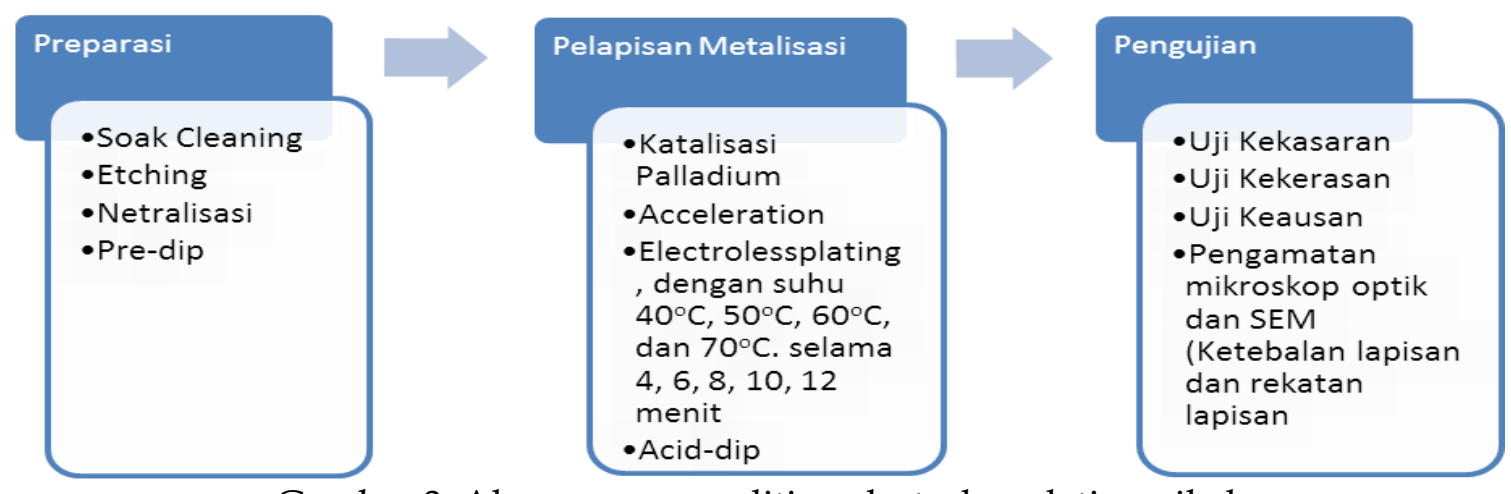

Gambar 3. Alur proses penelitian electrolessplating nikel

\section{Proses persiapan}

a. Tahap pembersihan (soak cleaning) dan penghilangan bahan pengotor pada permukaan spesimen. Pembersihan dilakukan dengan memasukkan specimen selama 7 menit ke dalam larutan soak cleaning terdiri dari sodium karbonate $\left(\mathrm{Na}_{2} \mathrm{CO}_{3}\right)$ dan trisodium phospat $\left(\mathrm{Na}_{3} \mathrm{PO}_{4}\right)$ dipanaskan dan dijaga pada tempetature 50 $-70^{\circ} \mathrm{C}$. Tahap soak cleaning diikuti rinsing pada suhu ruang selama \pm 30 detik.

b. Tahap Etching untuk membentuk pori-pori dalam skala mikroskopis serta membuat permukaan menjadi kasar pada permukaan plastik ABS. Proses etching menggunakan larutan asam kromat $\left(\mathrm{H}_{2} \mathrm{CrO}_{4}\right) 300$ gr dan asam sulfat $\left(\mathrm{H}_{2} \mathrm{SO}_{4}\right) 18 \mathrm{ml}$ selama 30 menit dengan suhu antara $60-70^{\circ} \mathrm{C}$. Pembentukan pori-pori dalam skala mikroskopis dapat mengubah sifat bahan dari hidrofobik menjadi hidrofilik sehingga ikatan adhesive mekanik antara substrat plastic ABS dengan logam menjadi lebih baik (Oliviera et.al., 2015). Spesimen dikeluarkan dari larutan dilanjutkan rinsing dalam suhu ruang selama \pm 30 detik.

c. Tahap netralisasi untuk menghilangkan asam kromat yang tertinggal pada permukaan setelah proses etsa yang tertinggal di dalam pori-pori permukaan plastik ABS. Proses netralisasi menggunakan larutan sodium sulfit $\left(\mathrm{Na}_{2} \mathrm{SO}_{3}\right)$ ditambahkan aquades sampai 1 liter dalam suhu ruangan selama 1 menit. Adanya larutan kromium yang mengendap dalam pori-pori hasil proses etching dapat menghambat ikatan yang baik antara plastic dengan logam ketika proses elektrolessplating (Equbal, and Sood, 2014). Spesimen dikeluarkan dari larutan dilanjutkan rinsing dalam suhu ruang selama \pm 30 detik.

d. Tahap pre-dip untuk meningkatkan efisiensi reaksi kimia pada tahap katalisasi dan menghilangkan larutan etsa yang tertinggal di permukaan plastik ABS. Proses pre-dip menggunakan $\mathrm{HCl} 37 \%$ sebanyak $100 \mathrm{ml}$ ditambahkan aquades hingga 1 liter pada suhu ruangan dan dicelupkan selama 1 menit kemudian dikeluarkan dari larutan dilanjutkan pembersihan rinsing dalam suhu ruang selama \pm 30 detik.

\section{Proses pelapisan metalisasi meliputi:}

a. Tahap katalisasi palladium untuk menghasilkan permukaan plastik bersifat metal sehingga lebih mudah untuk menerima ion-ion logam pada proses elektrolessplating maupun electroplating berikutnya. Bahan yang digunakan terbuat dari campuran $\mathrm{PdCl}_{2} / \mathrm{SnCl}_{2} 7 \%$ dicampur $\mathrm{HCl} 37 \%$. sebanyak $200 \mathrm{ml}$ kemudian ditambahkan aquades hingga menjadi 1 liter dalam suhu ruangan dan waktu proses 6 menit. Spesimen dikeluarkan dari larutan dilanjutkan proses rinsing dalam suhu ruang selama \pm 30 detik.

b. Tahap akselerasi berfungsi meningkatkan efektifitas reaksi pada saat proses elektrolessplating. Pada proses katalisasi palladium penggunaan paduan $\mathrm{PdCl}_{2} / \mathrm{SnCl}_{2}$ akan menghasilkan lapisan tipis timah pada permukaan. Lapisan timah akan menghalangi pembentukan lapisan logam pada proses elektrolessplating yang dilakukan. Lapisan timah bisa dilarutkan dalam larutan PS akselerator A yang terdiri dari campuran sodium hydrosida $(\mathrm{NaOH})$, tembaga sulfat $\left(\mathrm{CuSO}_{4}\right)$ dan ethylene diamine tetraacetic acid disodium $\left(\mathrm{EDTANa}_{2}\right)$ sebanyak $210 \mathrm{ml}$ dengan suhu 
ruangan dan waktu proses 5 menit, dilanjutkan proses rinsing.

c. Tahap elektrolessplating menggunakan larutan dari campuran, nikel sulfat $\left(\mathrm{NiSO}_{4}\right)$, sodium hidroksida $(\mathrm{NaOH})$, sodium hydrogen phospate $\left(\mathrm{Na}_{2} \mathrm{HPO}_{4}\right)$, dan amonium klorida $\left(\mathrm{NH}_{4} \mathrm{Cl}\right)$, dicampur aquades hingga 1 liter. Elektrolessplating dilakukan untuk menghasilkan lapisan metalize sebagai dasar konduktif pada proses electroplating. Proses elektrolessplating dilakukan dengan memvariasi suhu larutan yaitu $40^{\circ} \mathrm{C}, 50^{\circ} \mathrm{C}$, $60^{\circ} \mathrm{C}$, dan $70^{\circ} \mathrm{C}$ selama 8 menit. Sedangkan variasi waktu proses elektrolessplating yaitu 4 mrnit, 6, mrnit, 8 menit, 10 menit, dan 12 menit dengan suhu larutan $50^{\circ} \mathrm{C}$.

\section{Pengujian yang dilakukan adalah}

a. Pengujian kekasaran permukaan dengan alat Surface Roughness Tester tipe DR220 dilakukan sebanyak 5 kali pengukuran dengan panjang pengukuran $2,5 \mathrm{~mm}$.

b. Pengujian keausan dengan metode disk on block untuk mengetahui keausan spesifik material. Pengujian dilakukan dengan pemberian beban gesek dari cincin yang berputar (revolving disc) secara berulangulang sehingga sebagian material pada permukaan akan terkelupas. Laju keausan dinyatakan dengan jumlah kehilangan/ pengurangan material (massa, volume,atau ketebalan) tiap satuan panjang luncur specimen dengan satuan waktu. Keuasan spesifik (Ws dalam $\mathrm{mm}^{3} / \mathrm{kg}$ ) dinyatakan dengan persamaan:

$W_{s}=\frac{B \cdot b \varphi^{g}}{8 \cdot P_{0} \cdot l_{a}}$

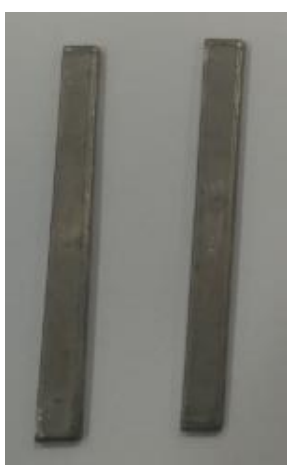

(a) dengan: $\mathrm{B}=$ lebar disk $(\mathrm{mm})$, bo = lebar keuasan pada benda uji $(\mathrm{mm}), \mathrm{r}=$ jari-jari $(\mathrm{mm})$, Po = beban tekan $(\mathrm{kg})$, lo = jarak tempuh dari proses pengausan $(\mathrm{mm})$

c. Kekerasan merupakan ketahanan suatu material terhadap penetrasi benda lain Pengujian kekerasan menggunakan shore hardness tester (durometer) tipe $\mathrm{D}$ dengan menghitung resistensi material setelah diberi penetrasi jarum pada permukaan dengan beban yang telah ditentukan. Durometer digunakan untuk mengukur material non logam seperti: kaca, akrilik, resin, ebonite maupun fiber.

d. Pengukuran ketebalan lapisan menggunakan Metallurgical microscope optic Olympus BX53M dan juga untuk mengamati struktur mikro plastik dan lapisan permukaan hasil pelapisan.

\section{HASIL DAN PEMBAHASAN}

\section{Hasil Elektrolessplating}

Keberhasilan proses elektolessplating ditunjukkan dengan perubahan warna menjadi lebih kelabu (sesuai dengan warna nikel). Pelapisan berhasil apabila warna kelabu merata menyelimuti seluruh permukaan bahan plastik ABS seperti pada Gambar 4.a.

Namun, terdapat kegagalan proses karena tidak terbentuknya lapisan nikel secara merata pada permukaan plastik ABS. Hal ini dipengaruhi oleh beberapa parameter seperti proses persiapan yang tidak sempurna (material kotor), kegagalan proses etching dan lama waktu aktivasi palladium. Kegagalan pembentukan lapisan nikel pada permukaan aluminium dapat ditunjukkan pada Gambar 4.b.

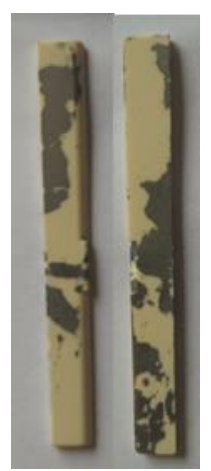

(b)

Gambar 4. Hasil proses elektrolessplating nikel

(a) Pelapisan yang berhasil,

(b) Pelapisan yang gagal 


\section{Hasil Pengukuran Ketebalan Lapisan}

Pengukuran ketebalan lapisan nikel hasil elektrolessplating pada plastik ABS diukur menggunakan mikroskop optik (Gambar 5.a dan 5.b). Hasil pengukuran ketebalan lapisan dapat dilihat pada Gambar 5.c dan 5.d.

Gambar 5.c menunjukkan peningkatan suhu proses elektrolessplating meningkatkan ketebalan lapisan sampai suhu $50^{\circ} \mathrm{C}$ sebesar $5,56 \mu \mathrm{m}$ dimana pada suhu $40^{\circ} \mathrm{C}$ sebesar 2,23 $\mu \mathrm{m}$. Peningkatan suhu lenoh lanjut menurunkan ketebalan lapisan, ditunjukkan pada suhu $60^{\circ} \mathrm{C}$ dan $70^{\circ} \mathrm{C}$ ketebalan lapisan berturut-turut adalah $4,57 \mu \mathrm{m}$ dan $3,72 \mu \mathrm{m}$. Peningkatan suhu sampai $50^{\circ} \mathrm{C}$ dapat mempercepat laju reaksi ion-ion untuk menempel dan mengendap pada pori-pori yang terbentuk pada plastik. Namun, peningkatan suhu lebih lanjut menyebabkan pergerakan ion-ion lebih cepat lagi akibatnya junlah ion yang mengendap pada permukaan

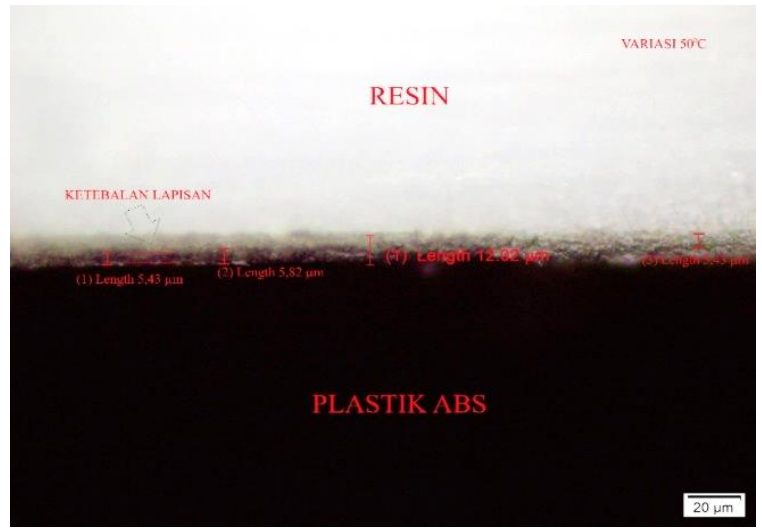

(a)

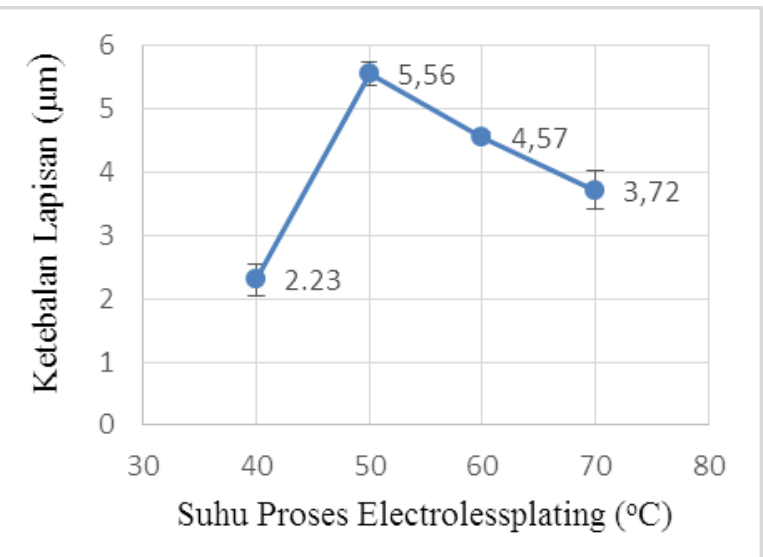

(c) menjadi lebih sedikit. Disamping itu suhu yang lebih tinggi memungkinkan penguapan larutan kimia menjaid lebih cepat.

Semakin lama waktu proses elektrolessplating menyebabkan semakin banyak ion nikel yang mengendap menjadi logam nikel yang melapisi permukaan plastic ABS semain tebal. Hal ini dapat dilihat pada Gambar 5.d, di mana grafik ketebalan lapisan semakin meningkat dengan waktu proses elektrolessplating yang semakin lama. Sampai waktu 8 menit ion-ion nikel masih mengisi pori-pori permukaan plastic ditunjukkan dengan penambahan ketebalan yang rendah sebesar 2,08 $\mu \mathrm{m}$. Namun, untuk waktu 10 menit proses elektrolessplating ketebalan lapisan nikel bertambah secara merata.ditunjukkan dengan penambahan lapisan yang cukup signifikan sebesar $4,01 \mu \mathrm{m}$ dan $4,51 \mu \mathrm{m}$ untuk proses selama 12 menit.

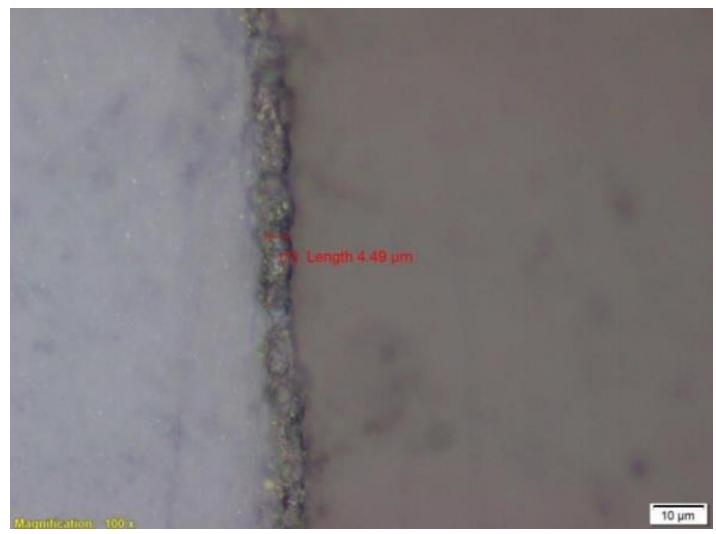

(b)

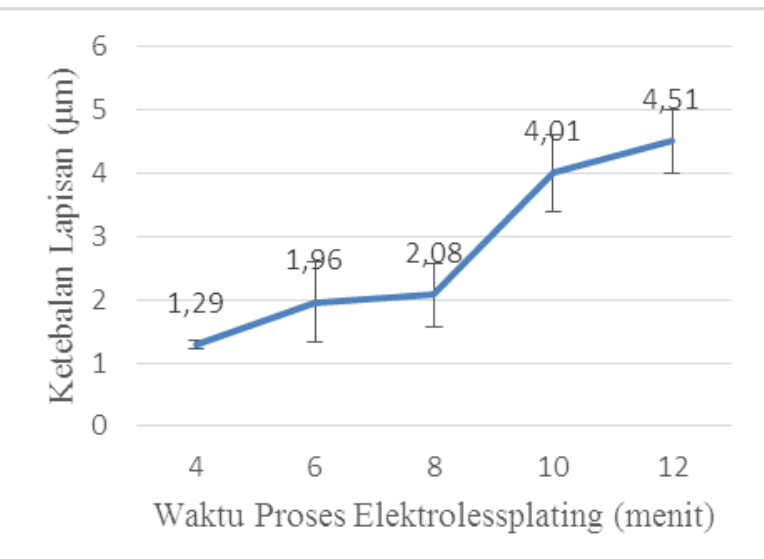

(d)

Gambar 5. Pengaruh suhu dan waktu proses elektrolessplating nikel terhadap ketebalan lapisan

(a) Hasil uji ketebalan pada spesimen untuk suhu elektrolessplating $50^{\circ} \mathrm{C}$

(b) Hasil uji ketebalan pada spesimen untuk waktu elektrolessplating 10 menit

(c) Pengaruh suhu larutan terhadap ketebalan lapisan

(d) Pengaruh waktu pelapisan terhadap ketebalan lapisan 


\section{Hasil Pengujian Kekasaran Permukaan}

Plastic ABS yang telah diproses elektrolessplating nikel diukur kekasaran pemukaannya di 3 titik berbeda untuk setiap specimen. Semakin tinggi suhu larutan elektrolit yang digunakan pada proses elektrolessplating menyebabkan kekasaran permukaan menjadi semakin bertambah seperti dapat dilihat pada Gambar 6.a. Nilai kekasaran semakin bertambah walaupun tidak terlalu banyak di mana pada suhu $40^{\circ} \mathrm{C}$ sebesar 0,17 $\mu \mathrm{m}$ menjadi $0,42 \mu \mathrm{m}$ pada suhu $70^{\circ} \mathrm{C}$. Hal Ini menunjukkan kekasaran permukaan lapisan nikel cukup merata untuk setiap specimen.

Suhu elektrolessplating memiliki pengaruh pada kekasaran permukaan. Peningkatan suhu elektrolessplating membuat pori-pori permukaan semakin besar sehingga permukaan menjaid semakin kasar. Akibat pori-pori yang semakin besar maka lapisan permukaan oleh ion-ion nikel semakin tebal pada permukaan plastik. Namun peningkatan ketebalan lapisan yang tidak merata pada struktur permukaan menyebabkan kekasaran permukaan meningkat. Nilai kekasaran lapisan nikel pada proses electroplating akan meningkat ketika suhu operasional semakin tinggi (Basmal, dkk., 2012).

Semakin lama waktu proses elektrolessplating menyebabkan kekasaran permukaan lapisan nikel semakin berkurang, seperti terlihat pada Gambar 6.b. Kekasaran permukaan sebesar 0,87 $\mu \mathrm{m}$ untuk lama waktu proses elektrolesspating 4 menit menjadi $0,44 \mu \mathrm{m}$ untuk waktu 8 menit dan $0,30 \mu \mathrm{m}$ untuk waktu 12 menit hampir sama dengan kekasaran permukaan pada suhu $60^{\circ} \mathrm{C}$ pada Gambar 6.a. Permukaan lapisan nikel semakin halus karena proses reduksi dari ion-ion nikel oleh natrium hipofosfit akan berlangsung semakin lama dengan bertambahnya waktu proses elektrolessplating. Natrium hipofosfit mampu mengurangi ion nikel dalam larutan menjadi logam nikel pada substrat logam dan juga pada substrat plastik setelah diaktifkan dengan partikel palladium. Dengan metode ini, film nikel-fosfor yang tahan lama dapat melapisi benda-benda dengan permukaan yang tidak beraturan (Abrantes, 1994). Semakin banyak ion-ion nikel yang mengendap dan mengisi pori-pori pada permukaan plastik sehingga permukaan menjadi halus.

\section{Hasil Pengujian Kekerasan}

Nilai kekerasan material dasar plastik ABS hasil pengujian sebesar sebesar 84,0 Shore Hardness Number tipe-D (SHN-D). Variabel suhu larutan dan lama waktu proses elektrolessplating tidak signifikan menmpengaruhi nilai kekerasan specimen seperti terlihat pada Gambar 7.a dan 7.b. Hal ini disebabkan karena tebal lapisan nikel pada permukaan hanya tipis, sehingga logam nikel belum mampu memberikan pengaruh terhadap kekerasan permukaan. Dengan demikian, hasil pengujian yang didapatkan masih merupakan hasil pengukuran kekerasan plastic ABS sebagai material dasarnya.

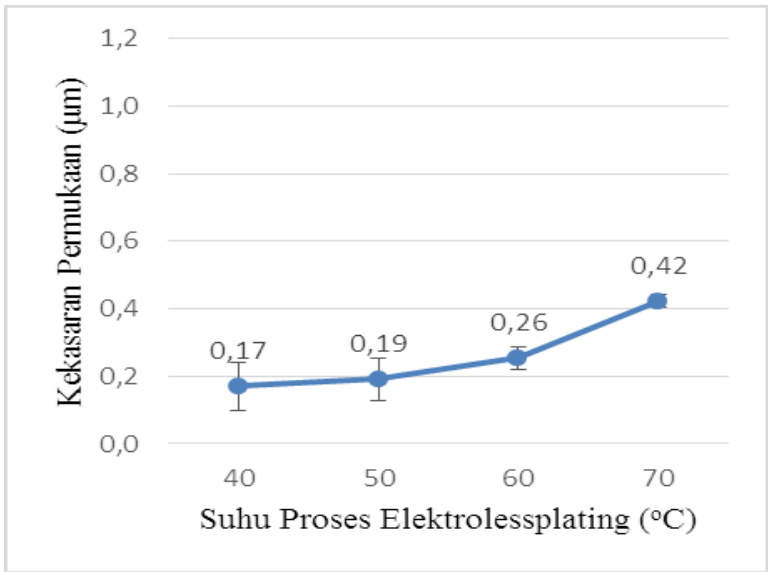

(a)

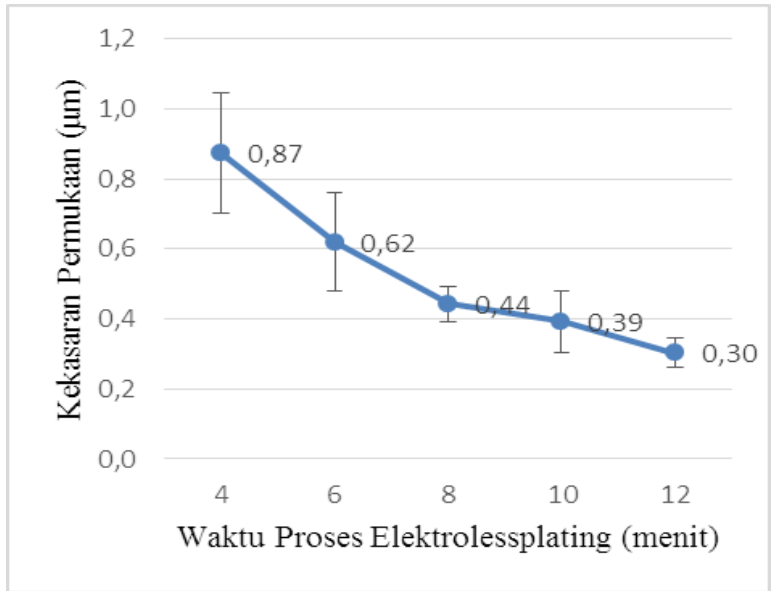

(b)

Gambar 6. Pengaruh suhu dan waktu terhadap kekasaran permukaan elektrolessplating nikel

(a) Pengaruh suhu larutan terhadap kekasaran permukaan

(b) Pengaruh waktu proses pelapisan terhadap kekasaran permukaan 


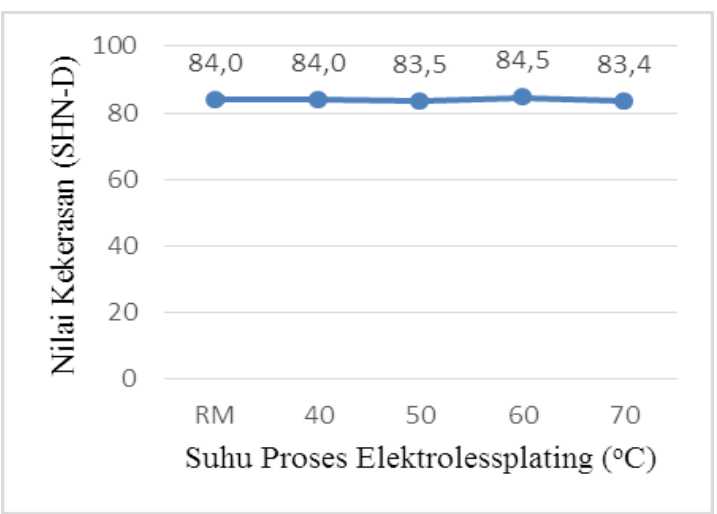

(a)

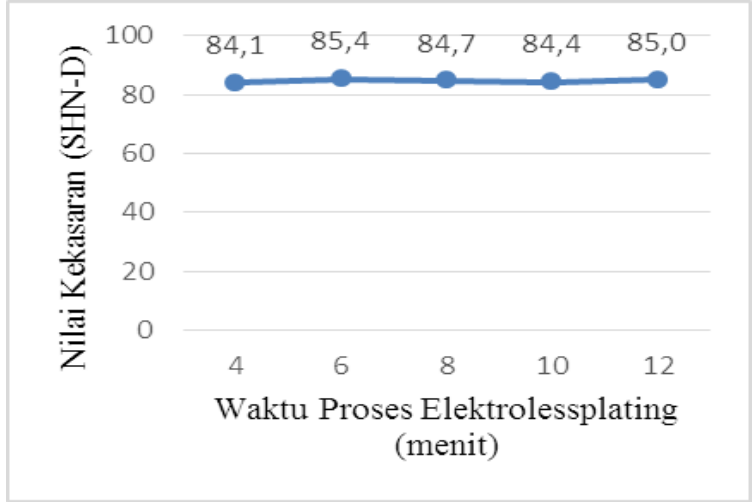

(b)

Gambar 7. Nilai kekerasan plastic ABS setelah proses elektrolessplating nikel

(a) Pengaruh suhu larutan terhadap nilai kekerasan specimen

(b) Pengaruh waktu proses pelapisan terhadap kekerasan spesiemen

\section{Hasil Pengujian Keausan}

Hasil pengujian keausan dengan mengukur lebar goresan bekas gesekan piringan pengaus selanjutnya dihitung nilai keuasan spesifiknya. Hasil penghitungan keausan spesifik seperti terlihat pada Gambar 8.

Penambahan suhu larutan dan lama waktu proses elektrolessplating nikel akan menurunkan keausan spesifik plastic ABS yang mana hal ini menunjukkan plastic ABS menjadi semakin tahan terhadap gesekan. Gambar 8.a menunjukkan bahwa pada suhu $40^{\circ} \mathrm{C}$ nilai keausan spesifik sebesar $3 \times 10^{-3} \mathrm{~mm}^{2} / \mathrm{kg}$ menjadi $0,962 \times 10^{-3} \mathrm{~mm}^{2} / \mathrm{kg}$ pada suhu pelapisan $50^{\circ} \mathrm{C}$. Nilai keausan spesifik semakin turun untuk suhu $60^{\circ} \mathrm{C}$ dan $70^{\circ} \mathrm{C}$ namun tidak terlalu signifikan sebesar $0,499 \times 10^{-3} \mathrm{~mm}^{2} / \mathrm{kg}$ dan $0,232 \times 10^{-3} \mathrm{~mm}^{2} / \mathrm{kg}$. Demikian juga semakin lama waktu proses elektrolessplating akan menurunkan keausan spesifik seperti terlihat pada Gambar 8.b. Proses elektrolessplating selama 4 menit, keausan spesifik sebesar $2,62 \times 10^{-3} \mathrm{~mm}^{2} / \mathrm{kg}$ menjadi $1,26 \times 10^{-3} \mathrm{~mm}^{2} / \mathrm{kg}$ untuk waktu 8 menit dan $0,66 \times 10^{-3} \mathrm{~mm}^{2} / \mathrm{kg}$ untuk waktu 12 menit. Semakin rendah keausan spesifik menunjukkan ketahanan aus menjadi semakin meningkat.

Ketebalan lapisan permukaan memiliki korelasi dengan ketahanan aus. Peningkatan suhu larutan menyebabkan semakin banyak ion nikel yang terbentuk dan semakin lama waktu pelapisan maka semakin banyak ion yang menempel dan mengendap menjadi logam nikel pada permukaan plastik. Semakin banyak nikel yang terbentuk pada permukaan plastic maka semakin tahan terhadap gesekan (Hokkirigawa \& Kato, 1989).

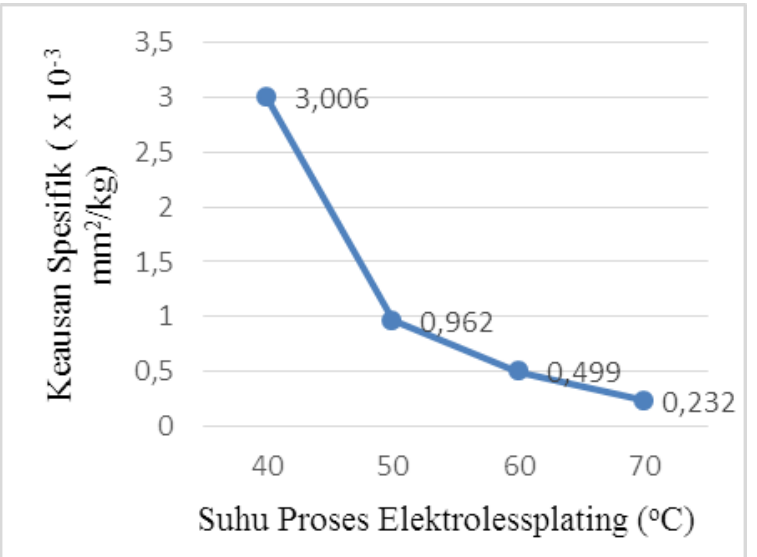

(a)

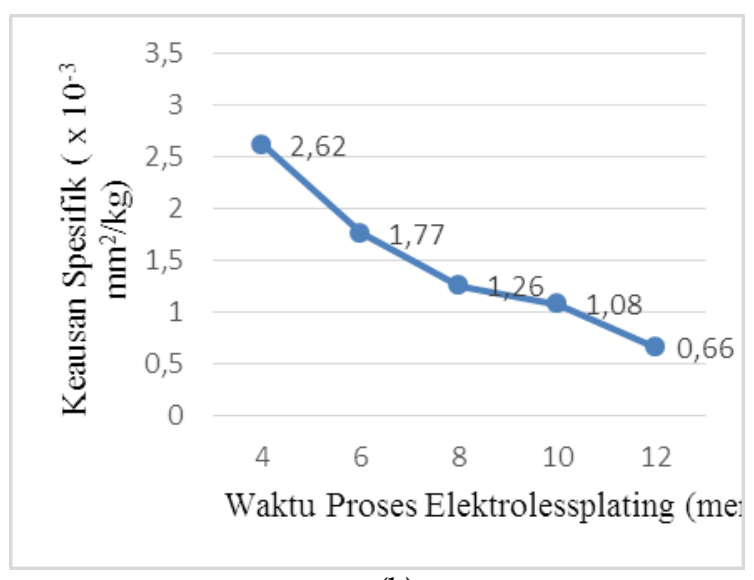

(b)

Gambar 8. Nilai keausan spesifik plastic ABS setelah proses elektrolessplating nikel

(a) Pengaruh suhu larutan terhadap keuasan spesifik

(b) Pengaruh waktu proses pelapisan terhadap keausan spesifik 


\section{KESIMPULAN}

Hasil penelitian menunjukkan bahwa peningkatan suhu larutan elektrolit dapat meningkatkan kekasaran permukaan lapisan dari $0,170 \mu \mathrm{m}$ menjadi $0,422 \mu \mathrm{m}$, namun semakin lama waktu pelapisan dapat menghaluskan permukaan lapisan dari $0,70 \mu \mathrm{m}$ menjadi $0,33 \mu \mathrm{m}$. Peningkatan suhu larutan elektrolit akan meningkatkan ketebalan lapisan sampai suhu $50^{\circ} \mathrm{C}$ sebesar $5,56 \mu \mathrm{m}$ namun pada suhu $60^{\circ} \mathrm{C}$ dan $70^{\circ} \mathrm{C}$ ketebalan lapisan berkurang sebesar 4,57 $\mu \mathrm{m}$ dan 3,72 $\mu \mathrm{m}$. Semakin lama waktu proses elektrolessplating maka ketebalan lapisan akan semakin meningkat berturut-turut sebesar 1,29 $\mu \mathrm{m}, 1,97$ $\mu \mathrm{m}, \quad 2.07 \mu \mathrm{m}, 3,34 \mu \mathrm{m}$, dan 3,98 $\mu \mathrm{m}$. Peningkatan suhu larutan elektrolit dan lama waktu proses elektrolessplating tidak meningkatkan kekerasan plastik ABS secara signifikan dimana kekerasan rata-rata sebesar 84 SDH sampai 85 SDH. Peningkatan suhu larutan elektrolit pada proses elektrolessplating menurunkan nilai keausan spesifik sebesar $1,90 \times 10^{-3} \mathrm{~mm}^{2} / \mathrm{kg}, 1,30 \times 10^{-3} \mathrm{~mm}^{2} / \mathrm{kg}, 0,88 \times$ $10^{-3} \mathrm{~mm}^{2} / \mathrm{kg}$, dan $0,42 \times 10^{-3} \mathrm{~mm}^{2} / \mathrm{kg}$ untuk suhu $70^{\circ} \mathrm{C}$. Semakin lama proses electroplating juga menurunkan keausan spesifik yaitu berturutturut $2,62 \times 10^{-3} \mathrm{~mm}^{2} / \mathrm{kg}, 1,77 \times 10^{-3} \mathrm{~mm}^{2} / \mathrm{kg}$, $1,56 \times 10^{-3} \mathrm{~mm}^{2} / \mathrm{kg}, \quad 1,08 \times 10^{-3} \mathrm{~mm}^{2} / \mathrm{kg}$, dan $0,66 \times 10^{-3} \mathrm{~mm}^{2} / \mathrm{kg}$ untuk waktu 12 menit. Untuk mendapatkan lapisan yang baik proses elektrolessplating dilakukan pada suhu 50 $60^{\circ} \mathrm{C}$ selama 10 menit.

\section{UCAPAN TERIMA KASIH}

Peneliti mengucapkan terima kasih kepada LP3M UMY yang telah mendanai penelitian ini sesuai dengan Surat Perjanjian Pelaksanaan Pekerjaan Hibah Penelitian Skema Kemitraan Dosen dan Mahasiswa, Unggulan Prodi, dan Multi Disiplin UMY Tahun 2018 nomor 1143/SP-2PL/LP3M-UMY/III/2018. Peneliti juga menyampaikan terima kasih kepada Erich Budiyanto, S.T dan Lukmanul Karim, S.T. yang telah membantu pelaksanaan penelitian sehingga karya tulis ilmiah ini dapat terselesaikan.

\section{DAFTAR PUSTAKA}

Abrantes, L. M. (1994). "On the Mechanism of Electroless Ni-P Plating". Journal of the Electrochemical Society. 141 (9): 2356.
Andinata, F., \& Munasir, K. (2013). Karakteristik Baja Komersial (ST 37) dengan Lapisan Ni-Co Sebagai Alternatif Bahan Anti Korosi Pada Lingkungan Asam. Jurnal Inovasi Fisika Indonesia, 2(1), 1-4.

Basmal, B., Bayuseno, A.P., Nugroho, S., (2012). Pengaruh Suhu dan Waktu Pelapisan Tembaga-Nikel pada Baja Karbon Rendah Secara Elektroplating Terhadap Nilai Ketebalan dan Kekasaran, Jurnal Rotasi, 14(2), 23-28.

Equbal, A., and Sood, K.A., (2014). "Metallization on FDM Parts Using the Chemical Deposition Technique." Coatings 4 (3): 574-586.

Harper, C. A. (2006). Handbook Of Plastic Processes. New Jersey: John Wiley \& Sons.

Hokkirigawa , K., \& Kato, K. (1989). Theoretical Estimation Of Abrasive Wear Resistance Based On Microscopic Wear Mechanism. (K. Ludema, Ed.) New York: Wear Of Materials.

Mujiarto, I. (2005). Sifat dan Karakteristik Material Plastik dan Bahan Aditif. Traksi, 3.

Nurhakim, B., Nikitasari, A., Sunardi, Mabruri, E., (2017). Pengaruh Suhu dan Waktu Pemanasan terhadap Karakteristik Lapisan Elektroles Ni-P pada Baja Tahan Karat Martensitik SS 420. Jurnal Sains Materi Indonesia, 18(4), 167-172.

Oliviera, S., H. B. Muralidhara, K. Venkatesh, K. Gopalakrishna, and C. S. Vivek. (2016). "Plating on acrylonitrilebutadiene-styrene (ABS) plastic." Springer Science 51 (8): 3657-3674.

Santhiarsa, I N. (2016). Pengaruh Temperatur Larutan dan Waktu Pelapisan Elektroles Terhadap Ketebalan Lapisan Metal di Permukaan Plastik ABS. Jurnal Teknik Mesin Universitas Udayana.

Santhiarsa, I N., (2010). Pengaruh Temperatur lapisan dan Waktu pelapisan Elektroles pada Proses Metalisasi Plastik ABS terhadap Kekerasan Lapisan,. Seminar Nasional Tahunan Teknik Mesin (SNTTM) ke-9 (pp. MIV-22). Palembang: Digital Prosiding SNTTM IX. 
Wang, H., Lei, X., Yao, S., \& Zhang, W., (2018). Effect of Heat Treatment on Properties of Ni-Sn-P Coatings. Jurnal Surface Engineering Institute Of Materials, Minerals And Mining, 34(6), 468-474.

Zohari, A., \& Kusmono. (2013). Pengaruh Komposisi Larutan, Variasi Arus dan Waktu Proses Pelapisan Crome pada Plastik ABS Terhadap Sifat Mekanis. Doctoral dissertation, Universitas Gadjah Mada.

PENUlis:

Muhammad Budi Nur Rahman

Program Studi Teknik Mesin, Fakultas Teknik, Universitas Muhammadiyah Yogyakarta, Yogayakarta, Indonesia.

Email: nurrahman_umy@yahoo.co.id, budinurrahman@umy.ac.id

\section{Cahyo Budiyantoro}

Program Studi Teknik Mesin, Fakultas Teknik, Universitas Muhammadiyah Yogyakarta, Yogayakarta, Indonesia.

Email: cahyobudi1971@gmail.com

\section{Sunardi}

Program Studi Teknik Mesin, Fakultas Teknik, Universitas Muhammadiyah Yogyakarta, Yogayakarta, Indonesia.

Email: sunardi.umy@gmail.com, sunardi@umy.ac.id 